УДК 7.036

Кісельова Катерина Олександрівна кандидат технічних наук, Київський національний університет культури і мистецтвв, Київ, Україна, katerinakiselova@gmail.com

\title{
ФОРМОТВОРЕННЯ ЄВРОПЕЙСЬКОГО ЖІНОЧОГО КОСТЮМА 70-Х РОКІВ ХХ СТОЛІТТЯ
}

Мета роботи: дослідження передумов і факторів виникнення моди 1970-х рp., характеристика популярних образів, стратегій та прийомів формотворення європейського жіночого костюма. Методологія дослідження. Розглянуто наукові роботи, присвячені історії, соціології, історії мистецтва та дизайну костюма. Використано методи соціокультурного, мистецтвознавчого, естетичного та структурно-композиційного аналізу. Застосовано візуальний метод дослідження. Наукова новизна роботи полягає у визначені комплексу основних складових життя суспільства й ступеню їх впливу на процеси формотворчості в 70-х рp. XX ст., та виявленні логіки розвитку композиційних, морфологічних і конструктивно-технологічних властивостей форм. Висновки. 70-ті pp. XX ст. характеризувалися великою різноманітністю модних жіночих образів. Загальна форма костюма значно змінювалася під впливом політичних, економічних і соціокультурних подій, наукових розробок того часу. Підвищення загального рівня життя, розвиток виробництва, інформатизація суспільства та активізація діяльності різних субкультур призвели до стихійного формотворення та виникнення дифузного стильового напряму. Принцип гармонії форми був відкинутий, а одяг повністю затвердився як засіб вираження індивідуальності людини.

Ключові слова: аналіз форми костюма, процес формотворення, розвиток форм одягу, мода 70-х рр. ХХ ст.

Киселева Екатерина Александровна кандидат технических наук, доиент, Киевский национальный университет культуры и искусств, Киев, Украина

Формообразование европейского женского костюма 70-х годов XX века 
Цель работы исследование предпосылок и факторов возникновения моды 1970-х гг., характеристика популярных образов, стратегий и приемов формообразования европейского женского костюма. Методология исследования. Рассмотрено научные работы, посвященные истории, социологии, искусства, дизайна и костюма. Использованы методы социокультурного, искусствоведческого, эстетического и структурно-композиционного анализа. Задействован визуальный материал. Научная новизна работы заключается в определенных комплексах основных составляющих жизни общества и степени их влияния на процессы формотворчества в 70-х гг. ХХ в. и выявлении особенностей развития композиционных, морфологических и конструктивно-технологических свойств форм. Выводы. 70-е гг. ХХ в. характеризовались широким разнообразием модных женских образов. Общая форма костюма значительно изменялась под влиянием политических, экономических и социокультурных событий, научных открытий того времени. Повышение общего уровня жизни, развитие производства, информатизация общества и активизация деятельности различных субкультур привели к стихийному формообразованию и возникновению диффузного стилевого направления, со спонтанным подбором элементов одежды, дополнений и аксессуаров. Принцип гармонии формы был отвергнут, а одежда полностью утвердилась как средство выражения индивидуальности человека.

Ключевые слова: анализ формы костюма, процесс формообразования, развитие форм одежды, мода 70-х гг. ХХ в.

Kyselova Kateryna, PhD in Technical Sciences, Assistant Professor, Kyiv National University of Culture and Arts, Kyiv, Ukraine

Formbuilding of European women's costume in the 1970s

Principal objective of this article is to study the background and factors contributing to the formation of the 1970s fashion, describe popular images, strategies and modalities of formbuilding of the European women's costume.

Methods. The review included about 20 scientific articles on the history, sociology, history of arts, history of design and costume. This article applied the methods of socio-cultural, art, aesthetic and structural and compositional analysis. Visual materials have been sourced from printed publications, magazines and Internet.

The scientific novelty of this work consists in the identification of main component parts of public life and their effect on formbuilding processes in the 1970s and logical construction of development of compositional, morphological and structural and technological properties of forms. 
Conclusions. The 1970s are characterized by high diversity of fashionable women images. The general shape of costume underwent significant changes in response to political, economic and sociocultural events, and scientific innovations of that time. Rise in the overall living standards, development of manufacturing, informatization of the society and activation of various subcultures led to spontaneous formbuilding and appearance of diffuse style trends with impulsive selection of items of clothing, supplementary elements and accessories. The principle of harmony in form was dismissed and the clothing started to be used as the method of expression of the person's individuality.

Key words: analysis of costume form, formbuilding process, development of clothing forms, fashion of the 1970s.

На початку XXI ст. розглядалися тенденції моди XX ст. Більшість дослідників вивчають еволюцію художніх стилів у костюмних формах $[1 ; 9 ; 13]$, розглядають костюм як частину матеріальної культури $[2 ; 10 ; 16]$, зосереджують увагу на соціальних проблемах виникнення та розвитку костюма $[7 ; 14 ; 15]$. Але, незважаючи на значну кількість робіт, присвячених моді, проблема вивчення закономірностей зміни та логіки розвитку форм костюма залишається малодослідженою. А саме ця особливість може надати найбільш цінну інформацію для дизайнера, якому потрібно заздалегідь передбачати актуальні форми одягу. На думку автора, це сталося через спрямованість дослідників на класичну мистецтвознавчу або на технологічну галузі без залучення інших чинників. Адже, дизайн потребує синтезу мистецтвознавчого, культурологічного, соціологічного та технологічного підходів до розгляду моди та розвитку форми костюма.

Розгляд процесів формотворення костюма найбільш розлого представлений в працях науковців Московського державного текстильного університету ім. А. Н. Косигіна (Московського текстильного інституту), опублікованих у збірнику під редакцією Т. В. Козлової [11]. Але в них аналіз форми проводиться за узагальненими зовнішніми ознаками, бо метою був вихід на чітке відсоткове прогнозування модних змін. Архітектонічний аспект форми костюма розглянуто в роботі Т. О. Бердник («Архитектоника костюма (Социокультурная динамика)», 2004). М. В. Кісіль, на матеріалі аналізу моди XX ст., спробувала сформулювати поняття «концепція формотворення» [5]. Е. А. Косарева описала динаміку змін костюма, здійснивши аналіз моди з позицій психології та соціології [7]. Дослідженню формотворення присвячено багато статей автора [6]. 
Підгрунття для вивчення форми костюма 70-х рр. ХХ ст. складають мистецтвознавчі роботи М. Б. Романовської («История костюма и гендерные сюжеты моды», 2010), Ш. Зеллінг [3]. Окремі описи форм костюма надані в роботах вітчизняних дослідників Л. П. Дихнич [2], О. М. Лагода [8], М. Т. Мельник [9], М. В. Сенько [13]. Натомість, жодне з мистецтвознавчих досліджень не дає відповіді на запитання «як створити модний актуальний одяг?», «які фактори необхідно враховувати?». Зважаючи на важливість дослідження логіки розвитку форм одягу, виявлення «інформаційних кодів» і трансформації їх в нову якість без втрати емоційної та художньої цінностей, була визначена тема дисертації автора «Художнє формотворення в дизайні костюма: історія розвитку, сучасні тренди».

Мета - дослідити передумови та фактори виникнення моди 1970-х р., характеристику популярних образів, стратегії, прийоми формотворення європейського жіночого костюма.

Межа 60-70-х рр. ХX ст. характеризувалася підвищеною соціальною напруженістю. Світовідчуття суспільства формувалося під «пресингом» тривожних подій в політиці («Червоний май» 1968 р. та відставка Ш. де Голля в Франції, конфлікт у Північній Ірландлії, «Свинцеві сімдесяті» в Італії, «Революція гвоздик» у Португалії, падіння «Чорних полковників» у Греції, Реставрація Бурбонів в Іспанії, масове проголошення незалежності колишніх британських колоній і протекторатів, дострокова відставка президента США Р. Ніксона тощо), в економіці (стрімке зростання цін на енергоресурси, зниження темпів економічного зростання, зменшення обсягів промислового виробництва, стагфляція, припинення урядом США конвертованості долара в золото, зростання безробіття). Світова політична нестабільність, безперечно, вплинула на соціокультурну сферу життя, що відобразилася на емоційно-психологічному стані суспільства.

На межі десятиріч молодь (яка переважала в кількісному відсотку в суспільстві, значно збільшився завдяки післявоєнному «бебі-буму») прагнула свободи, проявляючи протест проти будь-яких обмежень. Тінейджери початку 60-х, які виросли в умовах добробуту й мали все, що їм потрібно, наприкінці десятиріччя перетворилися в молодих людей, які не бачили сенсу свого життя в безкінечній гонитві за новими матеріальними благами, за умови відмови від власних уподобань. Для них система соціалізації особистості на основі споживчих стандартів і категорій престижності (на відміну від післявоєнного покоління їхніх батьків) виявилася штучною. Підвищення кількісних показників споживання на душу населення виявилося недостатнім для самореалізації людини. Молоді люди прагнули модно виглядати, витрачати гроші на подорожі, розваги, музику, але не готові були платити за це своїм життям. Особиста свобода здава- 
лася дуже цінною. Будь-яка примусовість, а з нею і будь-яка соціальна, релігійна чи державна системи здавалася злом. Подібні настрої об'єднали молодь 3 різними інтересами, віросповіданням 3 абсолютно протилежних соціальних шарів. Сформувалися нові протестні та контркультурні рухи, найвідомішими 3 яких на початку70-х були «хіпі», а наприкінці - «панки».

Двадцятирічні бунтарі, прагнули змінити світ, зробити його чистішим та чеснішим. «Старі форми життя були проголошені помилковими, а нові ще треба було знайти» [3, с. 410]. Не відчуваючи підтримки батьків, молоді люди об'єднувалися в комуни, засновані на принципах волелюбності та задоволення. «Формула «секс, наркотики, рок-н-рол» стала номінальною» [12, с. 182]. Протест молоді полягав не тільки в особливій поведінці, а й виборі певного образу та одягу, який був вираженням їхньої філософії. Довге волосся хіпі одночасно символізувало як повернення до природності, так і зневажливе ставлення до загальноприйнятих норм. Чоловіки припинили стригтися та голитися, жінки - голити ноги і пахви. Популярізації такого зовнішнього вигляду значно сприяли рок-музиканти, зокрема «Rolling stones», «Led Zeppelin» охоче використовували імідж бунтарів.

Ідеалізація минулого патріархального способу життя (на противагу напруженому темпу індустріального суспільства) призвело до неприйняття всього штучного й спочатку трансформувалося в моду на натуральні матеріали: вовну, бавовну, льон, а потім - у виникнення цілого напрямку «екомоди». Про популярність екологічного руху в суспільстві свідчить те, що саме в 1971 р. була заснована міжнародна організація «Green Pease» [12, с. 184]. Під впливом цих настроїв, форма одягу стала максимально спрощеною, з вираженою етнічною направленістю. Прототипи разом із філософією запозичувалися 3 культур східних країн: Індії, Непалу - або з традиційного одягу народів Центральної Америки, Балі і Марокко: яскраві сорочки - дашикі, кімоно, саронг, сарі, пончо тощо. Популяризації запозичень значно сприяли розповсюдження субкультури «хіпі», активізація антиколоніальних настроїв (у 1960-1970-х рр. 67 країни отримали незалежність), боротьба чорношкірого населення за права у США, творчість таких модельєрів як Ів Сен-Лоран, Зандра Роудс, Кензо Такада, а також хвиля гастарбайтерів («gastarbeiter» - робітник -іммігрант), кількість яких у Свропі досягла 7,5 млн. осіб [12, с. 116]. Флюорисцентні кольори поступилися природним відтінкам, почалася «бежева фаза» [3, с. 410]. Підкреслений геометризм та яскраві психоделічні малюнки оп-арту змінили дрібновізерункові та купонні орнаменти, характерні для народного одягу. Прості невибагливі форми, що нагадували полотняні сорочки, прикрашали за допомогою макраме, аплікації, вишивки, мережива, печворка, - всього, що можна було створити власноруч. Таким чином, на противагу масовості, уніфікації та стандартизації 1960-х рр., формувалася мода на вироби «лоу тек». 
Із народного одягу запозичили надмірну любов до аксесуарів. Ювелірні прикраси: намиста, браслети для рук і ніг, кільця для вух та носа, виконані з мексиканського, індійського чи марокканського срібла, мали особливе значення, їх прикрашали знаками східної езотерики (миру, любові, свободи тощо).

«Носити дозволялося що завгодно - від дешевого бавовняного одягу до розкішного вбрання «от кутюр». Сдина умова - щоб все це виглядало ненормально» [3, с. 413]. Ідею хіпі про те, що одяг повинен бути недорогим, зручним, легким у ремонті, краще секонд-хендівським, модна індустрія трансформувала у новий одяг із заплатками-аплікаціями, ефектами потертості та поношеності. Поступово анти-мода набула офіційності. Індустрія навіть навчилася використовувати гасла анти-моди задля просування брендів (дебютна колекція Кендзо Такада для європейського ринку 1970 р.).

Звичка хіпі вдягатися на барахолках перетворилася у комплектність і необхідність добору окремих складових одягу в індивідуальний гардероб замість строгої ансамблевості. Проте індустрія моди на противагу «барахолкам», ввела «базовий гардероб» (магазини пропонували розширені комплекти: 3 костюмом можна було купити набір сорочок, додаткову спідницю та брюки). Комплектування одягу з одиничних речей в єдиний образ не було всім під силу. Як наслідок з'явилися та набули нечуваної популярності універсальні рішення: біла футболка або сорочка та джинси. Їх із задоволенням стали носити і жінки, і чоловіки всіх вікових груп та соціальних верств. Деяким вони допомагали «дотягнутися до зірок», вийти на перший план, а деяким «спуститися 3 небес» та відчувати себе на рівних. Одяг переставав бути безперечною ознакою соціального статусу.

Широко розвинувся ринок готового одягу. У 1973 р. була заснована асоціація «Fédération française de la couture», що включала в себе окрім напряму високої моди також «Торгову асоціацію виробників готового одягу для жінок» та «Торгову асоціацію виробників готового одягу для чоловіків», що стало платформою для спільної роботи модельєрів і виробників [17]. Стилісти більше не ховалися за назвами фірм, для яких розробляли одяг, вони реєстрували власні марки: Соня Рікель, Клод Монтана, Террі Мюглер, Кензо Такада, Анна Марія Беретта, Жан Клод де Лука, Консей Ямамото, Шанталь Томас, Попі Морені, Емануель Кан, Елізабет де Сенневі, Анжело Тарлацці. 31973 р. дизайнери готового одягу двічі на рік представляли у Парижі свої колекції. Париж став центром промислової моди, 3'явилося поняття «нувель кутюр» (нова висока мода). У сер. 70-х рр. колекції prêt-à-porter демонстрували також у Мілані, Токіо, Лондоні та Нью-Йорку. Комерційний успіх став одним з основних критеріїв оцінки роботи «творців моди». 
Криза 1973 р. «закреслила мрії про ідеальний світ». Стрімке зростання цін на енергоресурси (ціни на нафту зросли з 3-х до 12 доларів за барель) поставило перед промисловістю та суспільством питання економічності. Функціональність стала першочерговою. Набули популярності специфічно-виробничі вимоги до одягу: стандартизація, уніфікація, мінімізація трудомісткості.

Мінімізація витрат була реалізована промисловістю у розробці моделей уніфікованих форм із використанням типових конструкцій за стандартними розмірами. Різними, в кращому випадку, були деталі, здебільшого матеріали та кольори. Набирало обертів виробництво товарів масового споживання. Дизайнери орієнтувалися на прості, лаконічні моделі, які можна було легко запустити у виробництво та продати якомога більшій кількості людей. Використання в одязі однакових елементів і матеріалів призвело до створення моделей, які могли носити як чоловіки, так і жінки. Статева ідентифікація була повністю нівельована, одяг вже не вказував на приналежність до певної статі. Ці зміни були підтримані зміцнілим феміністичним рухом. Жінки намагалися підкреслити, що в них $\epsilon$ не тільки сексуальність, але й інтелект. «Навіть голівудські зірки воліли демонструвати не розкіш та блиск, а власну компетентність» [3, с. 415]. Так реалізація вимог промисловості виявилася співзвучною настроями суспільства і сприяла виникненню та популяризації таких стильових напрямів як «мінімалізм» та «унісекс».

До сер. 70-х рр. кількість працюючих жінок у країнах з розвинутою економікою складала від $31 \%$ до $41 \%$ усіх працюючих [4, с. 243]. Професійна кар'єра накладала певні вимоги на формування гардеробу. Дуже популярним стає образ інтелектуальної жінки. Усі відхилення від норм у бізнес-сфері були табуйованими, отже, довжина «міні» залишилася далеко позаду, ій на зміну прийшли більш помірковані «за коліно» та «міді». Силует звузився та витягнувся, злегка розширюючись до низу. Модна пластика досягалася за рахунок використання м'яких тканин і трикотажу. Трикотаж був зручним і практичним, його властивості дозволяли задовольнити більшу кількість споживачів, і промисловість активно його впроваджувала. Популяризації такого одягу сприяла творчість талановитих дизайнерів Соні Рікель та Андре Курежа. Соня Рікель запропонувала трикотаж, стикнувшись 3 відсутністю зручного одягу для вагітних жінок, а Андре Куреж, який був активним альпіністом, запозичив форми спортивного одягу для його використання у повсякденному житті. Промисловість за короткий період освоїла широкий асортимент трикотажного одягу: товсті та тонкі джемпери, светри (найпопулярнішими 3 яких були «водолазки»), жакети (під пояс 3 коміромшалькою або кардигани), жилети, сукні, спідниці та брюки, пальта, майки, футболки, рейтузи, шапки, шарфи, шалі прикрасили гардероби модниць. 
Але поміркований образ протримався в моді недовго, нові фарби з'явилися завдяки глем-року, який поступово набирав популярності. Девід Боуі та Гарі Гліттер довели, що «унісекс» - це не обов'язково невиразність жінок, це можливість для виразності чоловіків. Гендерна різниця ще раз була «атакована», але не за рахунок універсальності, а за рахунок використання «жіночих» елементів в чоловічому одязі (облягаючий силует, блискучі тканини, яскраві кольори, пір'я, оборки, туфлі на підборах і платформі, високі чоботи, макіяж і фарбоване волосся). «Дискотеки, які спочатку були заповідниками гомосексуалістів, перетворилися на сцену для всіх, хто хотів продемонструвати себе» [3, с. 416]. Одяг у стилі «диско» приваблював екстравагантністю форм: щільно прилягаючі до тіла (комбінезони, боді, ліфи-корсети, ліфи-бюстгальтери, майки 3 великими розрізами), великі та об'ємні (прозорі спідниці, халати, топи 3 воланами та боа 3 пірїв). Використовувалися ефектні, недорогі синтетичні матеріали в найяскравіших отруйних відтінках i контрастних поєднаннях. Окрім того, все оздоблювалося пайєтками, люрексом, стеклярусом і бісером, який виблискував під променями прожекторів, викликаючи роздратування і збудження почуттів. Таким чином, стверджувалися відверта театральність і сексапільність образів, притаманних наступному десятиріччю. Моді на дискотеки сприяла кіноіндустрія за рахунок ряду популярних фільмів, апогеєм яких були «Лихоманка суботнього вечора» (1977).

Для привабливого вигляду на дискотеках потрібне було «ідеальне тіло», якого набували через дієти, заняття фітнесом та аеробікою. Культ спорту сприяв переходу від одягу для занять спортом до одягу спортивного напрямку для повсякденного використання. Трикотажні джемпери, теніски, спортивні костюми, легінси, кросівки, кепки затвердилися у гардеробі. Удосконалилися форми, урізноманітнилися й ускладнилися деталі, застосовувалася складна фурнітура, впроваджувалися нові способи технологічної обробки. На повсякденний одяг розповсюдився крій спортивного характеру: реглан і сорочковий 3 пониженою проймою і широким рукавом, з'явилися капюшони. Комбінезони і напівкомбінезони перейшли 3 робітничого та спортивного одягу в розряд повсякденного.

Iз сер. 70-х pp. на зміну миролюбним настроям початку десятиріччя прийшла агресивність політичних активістів. Несприятлива економічна ситуація, що впливала на життя молоді, яка страждала від масового закриття підприємств, безробіття і скорочення соціальних допоміг, сприяла активізації профашистських і терористичних угрупувань, які звинувачували в економічних проблемах мігрантів, особливо вихідців з Азії та Африки. У расизмі та нацизмі, вуличних бійках молоді люди 3 робітничих сімей шукали вирішення повсякденних проблем. Як правило, протест проявлявся і за рахунок зовнішнього 
вигляду. Скінхеди коротко стриглися, носили переважно чорні або камуфляжні джинси на тонких підтяжках (які мали семантичне значення), цепні ремені, джинсові куртки або «бомбери», армійські шнуровані черевики. Так популяризувався стильовий напрям «мілітарі».

Зневіра в майбутньому, відчай і повне несприйняття навколишнього світу, який неможливо було виправити (революція хіпі не вдалася), зумовили розквіт нечуваного нігілізму серед молоді, що згодом знайшло відображення в субкультурі «панк» (Punk - «бруд», «покидьки»). Філософія панків була філософією «втраченого покоління». Вони остаточно вирішили, що змінити світ на краще неможливо, майбутнього немає, тому і в житті, і в кар'єрі немає сенсу. Ці настрої відобразилися в поведінці та одязі, що викликало негативну реакцію у старшого покоління (яке після 60-х вже важко було чимось здивувати). Вони хуліганили в кінотеатрах, зухвало поводилися 3 поліцейськими та перехожими, з викликом одягали те, що було неестетичним (мішки для сміття, рвані футболки та джинси, заколоті булавками, шкіряні куртки з об'ємною фурнітурою, військові черевики), агресивно розмальовували обличчя та волосся флюорісцентно-отруйними кольорами. Задля підкреслення похмурого і трагічного образу вони прикрашали себе «символами смерті» (хрестами, черепами), шпильками у вухах і кільцями в носі. Все було розраховано на епатаж. Панки створювали свої костюми на основі еклектичного змішання одягу, купленого в second-hand, військової форми, списаної з армійських складів і будь-яких речей, які вони перетворювали в прикраси - ланцюгів, рибальських гачків, гільз від стріляних патронів, лез бритви тощо. Ця гострота і виразність зовнішнього вигляду була майстерно підхоплена Вівьєн Вествуд (Vivienne Westwood), яка трансформувала його в справжню моду.

Отже, в 70-х pp. ХХ ст. завдяки підвищенню загального рівня життя, розвитку виробництва, інформатизації суспільства, активізації діяльності різних субкультур (які виражали свою позицію через створення специфічних образів), нові тенденції в моді стали формуватися стихійно, що призвело до виникнення так званого дифузного стильового напряму, зі спонтанним добором елементів одягу, доповнень та аксесуарів, які, за правилами «гарного смаку» не мали поєднуватися між собою. Принцип гармонії форми був відкинутий. Жінки, які стали самостійними та незалежними, вже не боялися виглядати «немодними», вони перестали беззастережно копіювати журнали мод, а лише брали їх до відома, виокремлюючи те, що відповідало їхнім бажанням, потребам та смакам. Одяг перестав комплектуватися в залежності від стильового напряму, основна увага приділялася його функціональному призначенню. Форма одягу спростилася, що призвело до зближення соціальних статусів різних груп людей. 
Це було десятиліття лібералізму і нескінченної творчості, навіть деякого божевілля, через явну відсутність будь-яких стильових правил і стандартів. Різноманітність стильових напрямів, народжених в 70-ті вражає: ретро, етнічний, класичний, романтичний, фольклорний, циганський, хіпі, панк, білизняний, спортивний, сафарі, диско, унісекс тощо. Жоден із них так і не став домінуючим, визначальним для всього десятиріччя.

Значно розширився асортимент одягу та матеріалів, а також повністю зрівнялися права споживачів і творців моди у створенні модних тенденцій. 3'явилося поняття базового гардероба сформованого 3 необхідної кількості речей, що поєднювалися між собою. Це були однотонні блузи або блузи з великим яскравими принтами, спідниці-трапеції, брюки-кльош, туніки, комбінезони, кардигани, светри-водолазки, сукні А-подібного силуету, сукнісорочки. Саме в 70-х pp. XX ст. вишуканість прийомів і способів комплектування, які народжувалися в споживчій сфері стихійно, остаточно затвердило одяг як засіб вираження індивідуальності людини, їі унікального бачення світу.

\section{Список використаних джерел}

1. Блэкмен К. 100 лет моды / К. Блэкмен ; пер. Т. Зотина. - Москва : Азбука, КоЛибри, 2013. - 384 с.

2. Дихнич Л. П. Феномен моди в соціокультурних процесах XX ст. : автореф. дис. ... канд. іст. наук 17.00.01 / Дихнич Людмила Петрівна ; Київ. нац. ун-т. культури і мистецтв. - Київ, 2002. -20 с.

3. Зеллинг Ш. Мода. Век модельеров: 1900-1999 / Ш. Зеллинг; пер. Ю. Бушуева, Г. Яшина. - Koeln : Könemann, 2000. - 655 с.

4. Зидер Р. Социальная история семьи в Западной и Центральной Европе (конец XVIII - XX вв.) / Р. Зидер. - Москва : Гуманитарный изд. центр ВЛАДОС, 1997. - $301 \mathrm{c}$.

5. Кісіль М.В. Концепції формоутворення костюму в західно європейському дизайні XX століття: витоки, розвиток, тенденції: автореф. дис. канд. мистецтвознавства: 17.00.07 / Кісіль Марина Володимирівна; Харк. держ. акад. декоративного мистецтва. - Харків, 2010. - 20 с.

6. Кисельова К. О. Характеристика формоутворення жіночого костюма 50-х років XX століття / К. О. Кисельова // Українська культура: минуле, сучасне, шляхи розвитку.- Рівне : РДГУ, 2015. - Вип. 21. Т.1. - С. 101-109.

7. Косарева Е. А. Мода XX век. Развитие модных форм костюма / Е. А. Косарева. - Санкт-Петербург : Петербург. ин-т печати, 2006. - 468 с.

8. Лагода О. М. Художньо-образні особливості костюма в дизайні одягу кінця XX - початку XXI століття: автореф. дис. ... канд. Мистецтвознавства : 17.00.07 / Лагода Оксана Миколаївна; Харк. держ. акад. дизайна і мистецтв. Харків, 2007. - 22 с. 
9. Мельник М. Т. Мода в контексті художніх практик ХХ ст.: автореф. дис. ... канд. мистецтвознавства : 26.00.01 / Мельник Мирослав Тарасович; Київ. нац. ун-т культури і мистецтв. - Київ, 2008. - 19 с.

10. Михайлов С. М. История дизайна. В 2. т. Т. 1. : учеб. для вузов / С. М. Михайлов. - Москва : Союз дизайнеров России, 2002. - 277 с.

11. Основы теории проектирования костюма: учеб. для вузов / [Т. В. Козлова, Р. А. Степучев, Г. И. Петушкова и др.]; под ред. Т. В. Козловой. Москва : Легпромбытиздат, 1984. - 452 с.

12. Пономарев М. В. История стран Европы и Америки в Новейшее время : учеб. / М. В. Пономарев. - Москва : Проспект, 2010. - 416 с.

13. Сенько М. В. Образна еволюція європейської моди в контексті мистецьких стилів кінця ХІХ - XX століття: автореф. дис. ... канд. мистецтвознавства : 26.00.01 / Сенько Медея Валеріївна ; Київ. нац. ун-т культури і мистецтв. - Київ, 2009. - 19 с.

14. Crane Diane. Fashion and Its Social Agendas: Class, Gender, and Identity in Clothing. - Chicago University Press, 2000. - 294 p.

15. Entwistle Joanne. The Fashioned Body: Fashion, Dress and Modern Social Theory. - Polity Press, 2000. - 272 p.

16. Raizman David Seth. History of Modern Design. Upper Saddle River, NJ: Prentice Hall. - London : Laurence King Pub., 2004. - 400 p.

17. Fédération française de la couture: wikipedia [Electronic resource]. Mode of access : https://en.wikipedia.org/wiki/F\%C3\%A9d\%C3\%A9 ration_fran\%C3\%A7aise_de_la_couture -20.03.2017. - Last access: 2017. - Title from the screen 20.03.2017.

\section{References}

1. Blackman, C. (2013). 100 Years of Fashion Illustration. Moskva: Azbuka, KoLybry.

2. Dykhnych, L.P. (2002). The phenomenon of fashion in the socio-cultural processes of the $X X$-th century, Abstract of the $\mathrm{PhD}$ diss. (art. sci.). Kyiv National University of Culture and Arts.

3. Charlotte Seeling (2000). The century of fashion designers. Moskva: KONEMANN.

4. Zider, R. (1997). Social History of Family in the Western and the Central Europe (the end of XVIII-XX centuries). Moskva: Humanit. publishing center VLADOS.

5. Kisil, M.V. (2010). The Concepts of shaping costume in West European design of the XX century: sources, development, and trends, Abstract of the PhD diss. (art. sci.). Kharkiv State Academy of the Design and Art. 
6. Kyselova, K.O. (2015). Form-making characteristics of 1950s female costume.Ukrainska kultura: mynule, suchasne, shliakhy rozvytku [Ukrainian Culture: Past, Present and ways of development], issue. 21, vol 1. pp. 101-109.

7. Kosareva, E.A. (2006). Fashion XX century. Development of fashion forms of suit. Sankt-Peterburg: Petersburg institute of press.

8. Lagoda, O.M. (2007). Art-graphic costume peculiarities in fashion design at the end of the XX - the beginning of the XXI century, Abstract of the PhD diss. (art. sci.), Kharkiv State Academy of the Design and Art.

9. Melnyk, M.T. (2008). Fashion in artistic practices of the $20^{\text {th }}$ century, Abstract of the PhD diss. (art. sci.), Kyiv National University of Culture and Arts. $21 \mathrm{p}$.

10.Myhaylov, S.M. (2002). History of design. Moskva: Soyuz dizaynerov Rossii.

11.Kozlova T.V. (Ed.) (1984). Fundamentals of the theory of fashion design. Moskva: Legprombyitizdat.

12.Ponomarev M.V. (2010). Modern History of Europe and America, XVI-XIX century. Moskva: Prospekt.

13. Senko M.V. (2009). Fashion's image evolution in the context of art's styles at the end of the XIX - to the XX century, Abstract of the PhD diss. (art. sci.). Kyiv National University of Culture and Arts.

14. Crane, Diane (2000). Fashion and Its Social Agendas: Class, Gender, and Identity in Clothing. Chicago University Press.

15.Entwistle, Joanne (2000). The Fashioned Body: Fashion, Dress and Modern Social Theory. Polity Press.

16.Raizman, David Seth (2004). History of Modern Design. Upper Saddle River, NJ: Prentice Hall, London : Laurence King Pub.

17.Fédération française de la couture: wikipedia. Available at: $<$ https://en.wikipedia.org/wiki/F\%C3\%A9d\%C3\%A9

ration_fran\%C3\%A7aise_de_la_couture> [Accessde 20.03.2017]/

(C) Кісельова К. О., 2017 